\title{
Korean Student Perceptions of a CANVAS Based EFL Class During COVID-19
}

\section{- A Case Study}

\author{
Andrew Richards ${ }^{1}$, Stuart Jones ${ }^{2}$ \\ ${ }^{1}$ First Author, Assistant Professor, Dankook University, andyrichards@hotmail.com \\ ${ }^{2}$ Corresponding Author, Assistant Professor, Dankook University, stu11@hotmail.com
}

\section{Abstract}

This study was designed to examine the feelings and perceptions of English learners at a Korean university towards using CANVAS as an online teaching medium during the global COVID-19 pandemic. Data were collected from 129 students enrolled at a university in the greater Seoul area. A survey questionnaire consisting of a combination of multiple choice, Likert scale and open-ended questions was used as the primary data collection method. In addition, if consent was given, survey participants were contacted by e-mail to discuss responses in further detail. Data was analyzed using general qualitative analysis and discussed using descriptive statistics. The findings show that despite pandemic related disruption and some feelings of frustration related to the efficiency of the system, students were able to adapt quickly to using CANVAS as their main learning interface and were generally satisfied with it. In addition, they relied on a specific number of CANVAS functions which helped with the learning process and improvement of English ability. Administrational and educational implications of these findings as well as limitations are also discussed.

Key Words: EFL, COVID-19, CANVAS, General English Education, LMS 


\section{Introduction}

The global COVID-19 pandemic beginning in early 2020 caused a significant amount of disruption to the education sector. To prevent the spread of the virus and to ensure the safety of both staff and students, classes could no longer take place in brick-and-mortar classrooms. Instead, lessons were taught online using the internet and education platforms as a way for students and teachers to interact. This move greatly affected how university level classes were taught in South Korea, including English as foreign language (EFL) classes which are often included in university graduation requirements. This forced change in approach resulted in university students expressing their concerns regarding how effective these online lessons would be. In March 2020, in a survey of over 12,000 university students, over $80 \%$ expressed concerns with the quality of classes conducted online and more than $80 \%$ felt they were due at least a partial refund on their tuition fee due to dissatisfaction with the quality of lessons (Bakh, 2020)

Despite the initiation of a nationwide vaccination program beginning in February of 2021, it is unlikely that South Korea will achieve herd immunity until November 2021 at the earliest (Lee, 2021) which might mean upcoming academic semesters could continue to be affected by COVID related restrictions. Thus, it is still unclear when life will return to normal, and classes can once again be held on campus in a classroom. Furthermore, there is every possibility of future global pandemics happening (Sawyer, Free, \& Martin, 2021) which could once again result in the education sector being affected in similar ways.

The logical solution to moving classes online was to use a learning management system (LMS) which would serve as a virtual classroom to enable students and teachers to connect, take part in lessons, and share important course materials. As defined by Turnbull, Chugh, and Luck (2019), the function of an LMS is to "provide an interactive online learning environment and automate the administration, organization, delivery, and reporting of educational content and learner outcomes." (p.1). Social distancing protocols put in place as a consequence of the pandemic have resulted in LMSs becoming the sole medium of communication between teachers and students and they have become an integral part of present-day education (Maske, 2020). A wide range of LMSs are currently available to educators, some of which are free to use and others that require a subscription fee. They offer a different variety of features and functions that can be used by both teachers and students as part of the educational process. However, this case study will focus CANVAS which was the LMS predominantly used in this research context.

Given the unique circumstances presented by the pandemic, this case study was designed to examine how Korean university students felt about using CANVAS as an education interface in an EFL course. As discussed by Kim (2020) a number of tertiary level institutions in Korea which were using their own in-house LMS's at the onset of the pandemic suffered from technical issues which affected the quality of the online education they could provide. These issues included faculty and students not being able to access the LMS when needed, poor video quality, broken connections during classes, and attendance checks being unreliable. Consequently, a move towards third party LMS's such as CANVAS is being made. This study will attempt to understand what specific features and functions offered by CANVAS students found useful and also aims to discover which features of CANVAS helped students to improve their English ability.

\section{Literature Review}

\subsection{Overview of CANVAS}

CANVAS is an open source, cloud based LMS which was released in 2011 by Instructure, an educational technology company based in the US. It is one of the most rapidly expanding LMSs (See Figure 1; Edutechica, 2021) with over $80 \%$ of American and Canadian higher 


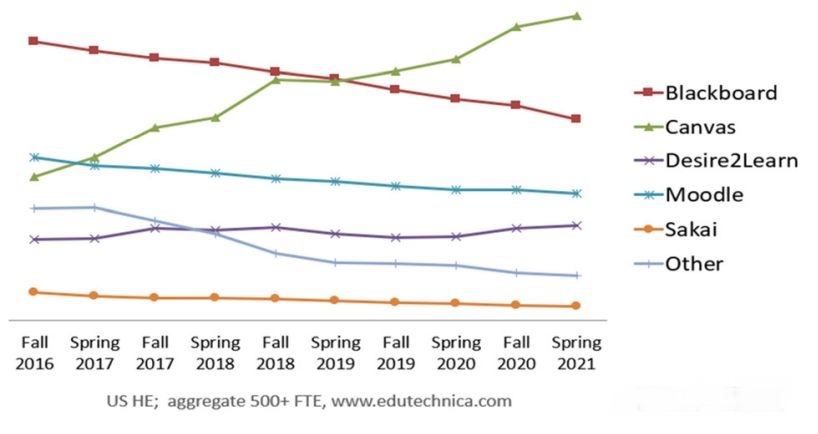

[Figure 1] LMS market share in U.S. Higher Education Fall 2016-2021 by institution. (Edutechica, 2021)

education institutes selecting it when negotiating new contracts (Hill, 2016). In addition to its increasing popularity, CANVAS is also regarded as being one of the most stable LMS systems with an uptime reliability rate of $99.9 \%$ (Rabah, 2017).

CANVAS offers a number of features and functions which can be used by both teachers and students which allow learners to view pre-recorded lectures, communicate with teachers, download course information, take quizzes online, and submit homework and classwork assignments. In addition, teachers can store class content, prepare and digitally deliver online assignments, create announcements for classes, and manage student grading (Daenos, Endozo \& Oluyinka, 2019). The initial splash page presents learners with six tabs and clicking on each tab directs learners to different sections of the LMS depending on what information they require or what they are looking to achieve. Below is a summary of these six tabs, their functions, and how they integrate into the LMS:

\section{Account}

This tab allows learners to edit their notification settings and view any files or media they have saved within the system. This is also where users can edit their password, change language settings, and alter their current time zone.

\section{Dashboard}

This section presents users with a tile overview of all the classes they are currently enrolled in along with basic information including course start date and finish date. Clicking on a class tile will direct students to a list of sub menus which contain important information relevant to each specific course. Here, users can access course materials, view syllabi, see assignment and quiz information, get feedback on submitted work via a personal comments box attached to each assignment, access course grades, and view course notification boards and chat rooms.

\section{Courses}

Similar to dashboard; however, courses are shown in list view and users are given the option to access courses which have already been completed.

\section{Calendar}

This tab presents a personalized calendar to users and can be viewed by week, month or by upcoming deadlines. An outline of upcoming assignments and quizzes is included alongside deadline information.

\section{Inbox}

Allows learners to send direct messages to either their teacher or other students in their class. Media and files can be attached to these messages if needed.

6. Help

Provides downloadable files to help students with any issues they may have with using CANVAS. Also provides links to download mobile apps that integrate for use on the go.

CANVAS, along with the other popular LMSs, such as Moodle, Blackboard and Desire2Learn all have a variety of functions and tools. However, there are several features which give Canvas an advantage over its competitors. A comparative functional review shows that CANVAS was preferred by faculty members as it completely dominated in every measure which included usefulness, usability, tool satisfaction, teacher effectiveness, and teacher efficiency 
(UITS, 2013). In terms of student satisfaction, CANVAS again excelled in all but one of the measures, comprising of: beneficial to learning, student efficiency and tool usefulness. Only Desire2Learn slightly edged out CANVAS in the usability measure. This same review also mentioned that CANVAS was the only platform to connect notification options to not only SMS text, but also to Twitter and Facebook. In addition, CANVAS was the only platform in the review to allow appointment scheduling, whereby the instructor reserves timeslots to allow students to sign up for a conference meeting.

\subsection{Student Satisfaction with CANVAS}

Since the use of LMSs, including CANVAS, has become more prevalent in higher education (Butakov et al., 2013; Hill, 2017; Klobas \& McGill, 2010; Paulsen, 2003; Weaver et al., 2008), it is now logical to suggest that they are now an integral part of the modern-day classroom. As a result, there has been a significant amount of research done on how students perceive the use of them as part of their education; however, the results so far have proved inconclusive. Some studies (Dooley et al., 2018; Green et al., 2018; Morton et al., 2016; Riddle and Gier, 2019) have shown that classes solely based on an LMS rather than face-to-face were more satisfying for the students and led to higher levels of academic achievement. Other studies (Krause \& Coates, 2008) indicate poor levels of student engagement with course content when classes were conducted online. On the other hand, other research (Pickering \& Swinnerton, 2019) shows very little significant difference between classes conducted in a traditional manner and those done online via an LMS.

There have also been several studies conducted which specifically relate to how learners perceive CANVAS as a learning platform. Wilcox et al. (2016) discovered that overall students liked the layout and appearance of CANVAS as well as finding it user-friendly. However, the same study also appeared to indicate some students felt specific functions and technologies offered on CANVAS did not work as well as they expected. In addition, they felt inconsistent organization of course content on the system led to some confusion. A further study by Dang (2020) showed master's degree students at a university in Sweden had a positive feeling about how CANVAS handled the administrative aspects of a class, such as course overview information, grading, and handling assignments. They also appeared to enjoy the flexibility and mobility offered by CANVAS and the integrated mobile applications. A different study by Kite et al. (2020) of students enrolled at a university in Australia found they considered CANVAS to be very limited in its ability to connect students and teachers and viewed it as more like a database into which teachers could store course content for learners to interact and engage with in their own time.

More specific to this project, other research has investigated how EFL learners feel about using CANVAS as part of their English lessons. One study (Khoeri, Nuraini, Ramdani, \& Agum, 2021) looked into how CANVAS functions could be used to improve English education. Through observations and questionnaires, the research showed it enhanced English learning and teaching due to its various features. These included sharing the class materials, creating discussions, allocating learning assignments and quizzes, communicating in online meetings, and collaborating with other platforms. The students who took part in this study enjoyed using the platform and thought it was fun to use. The only setback students had was gaining access to it but that was a network issue and not CANVAS related. In addition, research by Hajan and Padagas (2021) found similar results in a blended learning academic English writing class in the Philippines. The students liked several functions of CANVAS, and it was noted to be "an efficient, practical, convenient, and flexible Learning Management System (LMS) that afforded them social interactions between their peers and teachers." (p.103). The only issues that some students mentioned with CANVAS were the system interface and lack of training for both students and teachers. Similarly, another 
study (Soeung, Chaichompoo \& Nakanitanon 2020) from Pannasastra University in Thailand looked at how peer feedback using the functions of CANVAS influenced the students' writing ability in an English intensive course. The findings showed CANVAS functions had overall positive effects in 3 ways; by increasing their motivation, improving awareness with their spelling and grammar, and facilitating classroom management by allowing students a learning space of their own. One other study (Aliah, 2020) revealed the negative perceptions EFL learners had of CANVAS during a writing course due to common system errors and other unspecified technical errors. This study also found that using CANVAS led to a decrease in motivation to learn leading to a disconnect with the course content. Lee and Bailey (2016) examined how Korean students felt about receiving feedback on their work via CANVAS, but they did not cover overall perceptions of CANVAS as an LMS. Furthermore, this study focused on blended learning which involves both online and face-to-face classes. To add to this, a study in Boliva (Tango Rojas, 2020) on blended learning using CANVAS comprised of a comparison group and a treatment group. Both were EFL learners of the same ability, with the comparison group having regular face-toface classes and the treatment group being a blended learning class integrated with the CANVAS platform. The study looked at students' improvements in serval English skills between the groups. It showed that there was no considerable difference in improvements between both groups in the case of grammar, vocabulary and reading. In face-to-face classes, students could ask their teacher for a clear explanation if they did not understand. However, with CANVAS, the treatment group could replay and reread the content to help them fully understand. In terms of speaking, listening, and writing the comparison group performed better and improved as they had more opportunities to communicate and practice with classmates and the teacher, whereas the treatment group completed activities based on reading and grammar using the CANAVS tools.

Even though there has been considerable amount of research done in this area, it is logical to suggest that COVID-19 has and will continue to impact how EFL lessons at Korean universities are taught. A potential greater reliance on CANVAS is a clear possibility. Therefore, this study will attempt to add to the data extracted from the previously mentioned studies and answer the following research questions:

1. How comfortable were Korean EFL students using CANVAS for classes during COVID-19?

2. What features of CANVAS did Korean EFL students like or dislike?

3. What features of CANVAS did Korean EFL students find helpful to improve their English?

\section{Method}

\subsection{Participants and Research Context}

The data for this study was collected between June 6th and July 19th, 2021, at a university located in a metropolitan area of South Korea. This university requires all bachelor's degree students to pass two mandatory English classes in order to graduate. They are referred to as college English (CE) classes and each one focuses on a different skill: writing and presentation techniques.

Eight of these classes were taught by the authors of this research using the same asynchronous approach. A pre-recorded video which explained the class content was uploaded weekly for the students to watch in their own time along with an activity sheet based on concepts and ideas explained in the video. Students were required to submit the completed activity sheet by the end of the week. They were then reviewed by the teacher to ensure all students had understood the lesson. If needed, feedback on the student's work was provided either via the CANVAS Inbox or the comments box. Student attendance was then recorded based on the timely submission of the activity sheets and the quality of the work. In addition, occasional group activities and discussions were organized, and 
students were expected to participate in these using the functions provided by CANVAS. Homework, exams, and quizzes were also prepared and assigned on the LMS and given at various stages throughout the course.

Towards the end of the 2021 spring semester, students were asked if they would be willing to help with this project. Participation was voluntary and those who did not wish to help were under no obligation to do so. A survey was written in Korean and English and posted as an announcement on CANVAS to 1 advanced class, 2 basic classes and 5 intermediate classes. These levels were determined by a level test, which was loosely based on the TOEIC test of English proficiency and was administered by the education company YBM prior to the student's starting university. In total, 129 students responded to the survey and $65(52.4 \%)$ were male and $59(47.6 \%)$ were female. All students were South Korean and 113 (91.1\%) were freshmen, 2 (1.6\%) were sophomores, $6(4.8 \%)$ were juniors and $2(1.6 \%)$ were seniors. The students' majors varied from education to engineering to business. 7 (5.6\%) students were 19 years old, 69 (55.6\%) were 20 years old, $26(21 \%)$ were 21 years old, $12(9.7 \%)$ were 22 years old and $10(8.1 \%)$ were 23 or older. In terms of the student's levels, 35 (28.2\%) were assigned to a basic class, $81(65.3 \%)$ were in intermediate and the remaining $8(6.5 \%)$ were in advanced.

\subsection{Data Collection}

The data for this study was collected in two ways. Initially, the research team used Google Forms to design and write a survey questionnaire (Appendix A) in early May 2021. This method of data collection was chosen for several reasons. Firstly, it allowed for collection of a large set of anonymously submitted data which would develop a clearer understanding of how students felt about CANVAS. In addition, it could be posted online without the need for face-to-face interaction which was critical under the COVID restrictions at the time. Furthermore, according to Young (2016) a survey questionnaire is one of the most effective to establish feelings and perceptions towards certain ideas or objects which was the primary focus of this study. Following the survey creation, it was distributed to 6 colleagues of the research team who were not involved with this project. Comments and feedback from them regarding individual questions assisted in establishing validity prior to data collection. Once any required amendments had been made, it was posted on the announcements section on CANVAS for the participants to voluntarily complete in their own time. There were 34 questions in total with the initial 2 being pre-survey questions, the following 5 were related to demographic information. The remaining questions consisted of a combination of multiple choice, short answers along with 10-point Likert scale questions which the research team felt would reveal a wider spectrum of data which might not have been possible with a 5-point scale. Whilst it was not possible to run a reliability test on every survey question, a Cronbach Alpha test conducted on the Likert scale questions revealed a score of 0.93 indicating excellent internal consistency.

At the end of the data collection period, the results of the survey were automatically collated in an Excel spreadsheet by Google for analysis. The final question of the survey asked participants if they would be willing to be contacted to discuss some of their responses in more detail. Those who agreed were asked to leave their email address. During the data analysis phase of this study, any relevant responses deemed important to the research questions were pursued and discussed via email / online video call.

\subsection{Data Analysis}

Once all data were collected, the researchers individually explored and interpreted the participants' responses to the multiple choice and 10-point Likert scale questions and analyzed them through descriptive statistics, which helped to summarize the 129 respondents' responses and to identify some common themes and patterns of the 
data to establish any connections. For the open-ended questions and personal correspondence, content analysis was applied to identify and understand frequent trends in the textual data. Following this, the researchers met on four occasions for approximately 1 hour each time on a Zoom conference call to compare thoughts and concepts. Discussions were held to settle any differences and finalize the overall results.

\section{Results and Discussion}

\subsection{Comfort Levels with using CANVAS}

In order to try and answer research question 1, the participants were asked a number of questions based on how prepared they felt they were with using CANVAS prior to the semester, how long it took them to feel comfortable using the platform, and ultimately how easy they found using the LMS for classes during the pandemic.

Before answering the survey, all participants were asked control questions (Survey Questions 1 \& 2) which served two purposes. Firstly, to ensure all students were enrolled in at least one CE class, and secondly to check if those students used CANVAS as part of their classes. 124 of the 129 participants responded affirmatively thus continued to answer the main survey questions. The 5 who responded negatively were not able to access the main survey questions and that data was disregarded.

Given that more than $90 \%$ of the participants were freshman, it is possible to suggest they would have had little or no experience using CANVAS prior to beginning university. Consequently, having to adapt to a new LMS and more importantly a new way of taking classes due to COVID could have resulted in frustration or confusion with being forced to use this learning interface. However, the survey data shows mainly positive feelings towards using it as part of their CE course. For survey question 8 , over $85 \%$ of the participants selected 7 or higher on a 10 -point scale when asked about how easy they felt

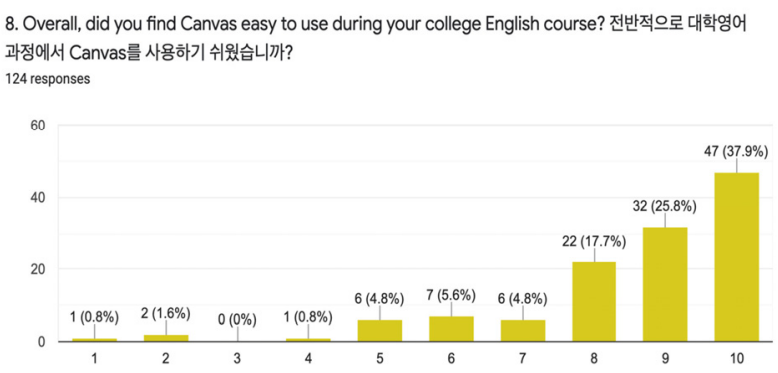

[Figure 2] Perceived Ease of use of CANVAS

CANVAS was to use (See Figure 2.) When asked to briefly explain in more detail one participant commented, "I would prefer to have class in person. I was not accustomed to using CANVAS at first, but I was able to learn the class material well enough." Another participant stated, "I really wanted to meet my teacher and classmates offline, CANVAS was ok, but I hope it will be offline next semester." This theme was reflected in several other comments suggesting that while it will never be able to replace a brick-and-mortar classroom, CANVAS is sufficient as an alternative given the circumstances.

Despite these general positive feelings, there are several interesting data points regarding how prepared the students were, and how quickly they were able to adapt to using CANVAS. When asked about how prepared they were to use this new system (Survey question 10), 38 (30\%) participants said they received no training or education prior to the start of the semester. Surprisingly, of those $38,30(78 \%)$ still answered 8 or higher to survey question 8 and only $3(0.07 \%)$ selected 5 or less. Furthermore, survey question 11 asked the participants how long it took them to get used to using CANVAS. The majority $(75.8 \%)$ indicated it took less than 4 days with the remaining 30 participants $(24.2 \%)$ claiming it took longer than 1 week. Out of these 30, 19 (63\%) continued by selecting 8 or higher for question 8 . In addition, of those 30 who said they received no CANVAS training, only $9(30 \%)$ said it took them 1 week or longer to feel comfortable with using it. These slight anomalies in the data appear to suggest that there is no clear link between either how much training students received and how long 
it took them to feel confident using the system with their overall satisfaction levels with using CANVAS. Similarly, there is also no identifiable pattern between how student majors, age, and English ability seem to affect their satisfaction levels with using this platform.

To summarize the data in relation to research question 1 , even though there appears to be some apprehension towards online learning and a clear desire to return to face-to face classes as soon as possible, Korean university EFL students were generally satisfied with CANVAS as a language learning interface. They were able learn the system relatively quickly and the amount of training they received does not appear affect the adaption rate. These findings appear to mirror those of several studies introduced in the literature review (Hajan \& Padagas, 2021; Khoeri et al., 2021; Wilcox et al., 2016) in which students in other countries and learning contexts indicated overall satisfaction with CANVAS. However, the findings of this study on how much training using CANVAS the students received differ greatly from those discovered by Hajan and Padagas (2021) in which a lack of training appeared to significantly affect their perceptions of CANVAS.

Overall, this data adds these studies by demonstrating that even during the unique circumstances created as a consequence of the ongoing global pandemic which has essentially forced learners into using this LMS, satisfaction levels with it remain reasonably high.

\subsection{Useful Features and Functions}

For the second research question, this study attempted to establish which features and functions offered by CANVAS were perceived as useful / helpful by tertiary Korean EFL learners. To do this, the participants were asked to respond to survey questions based on their experiences with using the different learning and course management tools built into the system. Survey question 12 asked the participants to select all the default CANVAS tools which they found useful in their CE class. The data collected from that question is collated in Table 1 .
〈Table 1〉 Most common perceived useful features of CANVAS

\begin{tabular}{l|c|c}
\multicolumn{1}{c|}{$\begin{array}{c}\text { Most common perceived } \\
\text { useful Features of CANVAS }\end{array}$} & n \\
\hline Lecture Contents & 91 & $73.4 \%$ \\
\hline Announcements & 69 & $55.6 \%$ \\
\hline Grades & 50 & $40.3 \%$ \\
\hline Assignments & 49 & $39.5 \%$ \\
\hline Quizzes & 49 & $39.5 \%$ \\
\hline Inbox & 36 & $29 \%$ \\
\hline Syllabus & 26 & $21 \%$ \\
\hline Dashboard & 26 & $21 \%$ \\
\hline Lecture Resources & 17 & $13.7 \%$ \\
\hline Calendar & 15 & $12.1 \%$ \\
\hline Comments Box & 9 & $7.3 \%$ \\
\hline Gradebook & 6 & $4.8 \%$ \\
\hline Discussion & 2 & $1.6 \%$ \\
\hline Open Board & 2 & $1.6 \%$ \\
\hline None & 2 & $1.6 \%$ \\
\hline Q \& A Board & & $0.8 \%$ \\
\hline
\end{tabular}

Unsurprisingly, the lecture contents, announcements, assignments, and grades sections were the most frequently selected. These four functions were vital to ensure students could keep up to date with the progress of the class, receive any important information, access course videos / materials, and track their progress with exams, quizzes, and assignments. They were also the sections that would have been used most by the teachers and without them it would have been virtually impossible to maintain any normality to online classes. However, the data indicates that there are a number of functions that would have been used a lot by the teachers, yet the students seem to feel they were not particularly useful for their class. For example, it was somewhat surprising how relatively infrequently the comments box, calendar and discussion were selected. Several of the responses to survey question 13 seemed to explain this in more detail. Participants commented on how they felt there were too many functions which they either did not use or did not understand how to use. One participant stated, "I only needed lecture contents and announcements to do most of the work, I don't know why there are so many other functions which did not get used." Another participant commented, "Lecture contents contained the videos and other class materials 
each week, without this I would not be able to keep up with the class, other things I only used three or four times in the semester."

This trend is also reflected in the questions which asked the participants about functions they found to be the most user friendly (Survey Question 14). Lecture contents and announcements were clearly deemed to be the most user friendly with $72.6 \%$ and $53.2 \%$ of participants selecting them respectively. Only $10(8.1 \%)$ respondents indicated they found the comments box easy to use, 9 (7.3\%) selected the calendar, and $2(1.6 \%)$ felt the discussion section was easy to use. Comments made to elaborate on these choices included: "I used lecture contents many times a week for this class and other classes. After one or two weeks it was very easy and convenient to use."; "Every Monday I checked announcements from my teacher and then entered lecture contents to complete the lesson for the week, it was very convenient."

When asked to specify which functions they found the most difficult to use, the most frequently selected answer was 'none' with slightly over $40 \%$ of participants selecting it. This indicates a large proportion of the participants had little problem using the functions that were provided by CANVAS. However, almost one third selected discussion and the two other most selected functions in this question were Q\&A board and open board with almost $20 \%$ selecting each one respectively. When asked about this in more detail, many students left comments that indicated they were not confident using online discussion tools like this. They seemed to feel they could not actively engage with other people in the discussion like they would if it was being done in-person. This data appears to indicate the participants found tasks such as questioning, and discussion are both more time consuming and more difficult for students online than they would be in a regular classroom. A selection of comments regarding this question can be seen in Table 2.

Communication between students and teachers in a classroom is an undeniably crucial part of the learning
〈Table 2〉 Comments regarding using discussion, Q\&A Board, and Open Board

"I did not feel confident writing my opinion in the discussion" "I like discussing things face-to-face, but online I cannot feel any motivation to express my ideas"

"Sometimes, too many comments were written very quickly, it was hard to follow the discussion and I could not contribute."

"I spent a lot of time thinking what to write in the discussion, it felt like a waste of time

"It felt like only a few students participated, I think many students were not comfortable expressing their ideas online."

"It took a long time to read other people's comments before I could add mine."

"It was ok to read other students ideas, but I did not really learn anything related to the class."

process. Particularly in language classes, learners being able to discuss and ask questions to each other as well as being able to ask the teacher about class content or for help with a specific task is a way to foster learning and improve student knowledge and understanding. In a regular face-to-face setting, this is never really an issue, it is relatively straightforward to ask a classmate a question or request help from the teacher, However, when classes are online, this becomes more difficult. Despite all the students being enrolled in the same online class, they may not have met each other in person before, they have never been introduced and know little if anything about their classmates. Similarly, other than weekly videos, the students will not have had a lot of interaction with their teacher. Survey question 18 tried to examine how easy the participants felt it was to communicate with both classmates via CANVAS while classes were done online. The responses were very mixed, and there is no clear indication as to whether the participants felt positively or negatively about this (See Figure 3 ). Since there were such a variety of answers to this question, the research team decided to contact some of the participants by email to better understand why they felt this way. Those who felt positively (answered 6 or higher to question 18) responded with comments indicating they felt reasonably comfortable reaching out to their classmates although there does appear to be some hesitation based on the fact, they had not met each other face to face. Comments 
18. Canvas tools used in my college English class helped me to communicate with my classmates. 대학영어 수업에 사용 된 캔버스 도구는 급우들과 의사 소통하는 데 도움이되었습니다. 124 responses

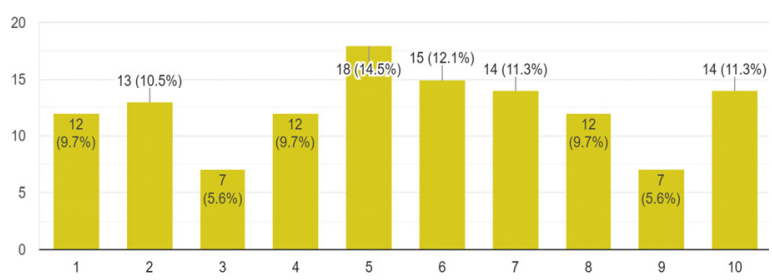

[Figure 3] Ease of communication between classmates

received by email regarding this question included: "I sometimes contacted other people in the class about the class and homework, but it felt a little rude because I did not know them." Another participant replied, "It was a little uncomfortable because I didn't know them, but I wanted ask for some help with my assignment.” There was a somewhat similar theme to the comments made by those who responded negatively to this question. Not meeting face to face or being introduced to each other appears to be a significant barrier to contacting classmates on CANVAS. One participant commented "I really wanted to know my classmates, but it was too uncomfortable to contact them by e-learning." In addition, several participants said they had no reason to get in touch with their fellow students. Everything they needed to learn was provided directly via e-learning and any question or problems they had could be handled by connecting the teacher directly. When asked about this, one participant commented, "I answered 2 for this question. I didn't need to contact my classmates and they did not contact me. My teacher prepared the lessons and sometimes I contacted him if I had a problem. Another similar comment, "I think my classmates could not help me with the class, I had no reason to ask them anything. Actually, in all my classes I did not contact my classmates even once."

Overall, this data appears to show students are willing to contact their classmates although some reluctantly given, they did not really know each other. Also, it appears students do not see any value in doing so. They are focused on learning the lesson content and it seems they feel their teacher is the only person they need to rely on.
However, there is a clearer pattern regarding how easy the participants felt it was to communicate with their teacher. $99(76 \%)$ of the participants answered higher than 7 on a 10-point scale when responding to survey question 20 indicating overall they found CANVAS was helpful. Despite these overall positive feelings, there still appears to be some frustration. Survey question 21 asked participants to briefly explain their answers to question 20. Several participants commented that asking questions to their teacher via CANVAS was a slow and cumbersome process. One participant commented "If you ask questions during an offline class, you can get answers right away. However, when it is an online class, I ask questions through a system such as an email or a note. You may get a quick reply, but when I asked my teachers last year, they all answered late." A different participant seemed to feel the same, commenting, "I thought it was inconvenient to ask questions that it would take time and not be solved immediately when there was something that I didn't know or understood." One of the participants, when contacted via email, expanded on this by saying:

"Also, there is a difference in expression between speaking and writing. There are problems such as writing down English grammar to ask questions using a computer system. That's why I think it's more comfortable to ask questions in person and deliver them well. Of course, the system is well established and I think it is enough to ask questions. However, I thought it was difficult to ask questions because it took time to send questions and get answers, and there was some inconvenience to express things that I didn't understand through chatting."

This is similar to the findings of a study by Kite et al. (2020). The participants in this research also found communication between classmates and the teacher on the LMS to be limited, as they viewed the LMS as a database for the teacher to upload course content for the students to complete in their own time.

One other aspect of CANVAS which this research 
attempted to examine was how well students were able to track their progress and receive feedback on their work (Survey questions 22, 23 and 24). Overall, the participants felt CANVAS helped them both in tracking their progress and receiving feedback. The data for questions 22 and 23 seem to mirror each other with exactly 97 (78\%) selecting over 7 on a 10-point scale for each question. One participant mentioned "I could see my score immediately after each quiz and after the submission deadline for the weekly work. I could also check my scores in the grades section and my progress rate in the learn status section which was very helpful to track my progress". Another participant made a positive comment concerning the feedback she received. She explained "I liked it when the teacher gave me feedback in the comments box after each homework and exam. I could see where I needed to improve but also the parts, I'm doing correct". The participants also appeared to feel any feedback they received via CANVAS was useful with almost $60 \%$ selecting higher than nine on a 10-point scale when answering survey question 25 and all participants choosing 5 or higher. There were no identifiable patterns relating to participants age, English level, or major in the data for these three survey items.

In summary, despite some negativity and feelings of frustration, the participants generally felt the functions and features offered by CANVAS were of use and did help them in their CE class. The vast majority (84\%) of those who completed the survey selected 7 or higher when answering survey question 26, the results of which can be seen in Figure 4. This is in-line with the comparative functional review mentioned in the literature review (UITS, 2013) that tool usefulness was scored highly by the participants along with other measures such as beneficial to learning and student efficiency of the LMS. In addition, our study mirrors the findings of the study by Soeung, Chaichompoo \& Nakanitanon in 2020 in Thailand, showing students overall had positive feelings of CANVAS functions.

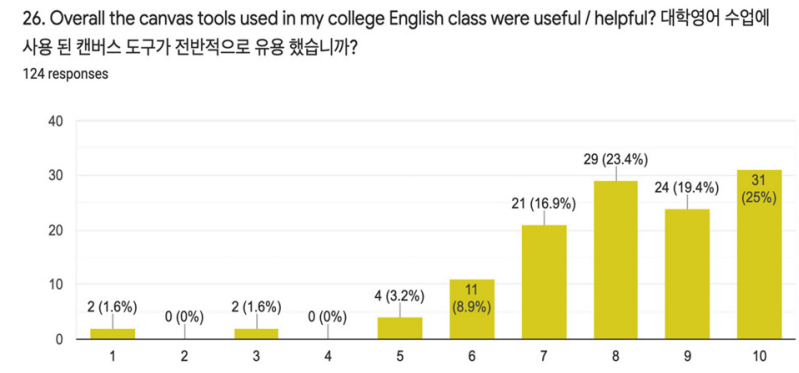

[Figure 4] Usefulness / helpfulness of CANVAS tools

\subsection{Features / Functions which Improved English Ability}

The final question of this study was to identify which features and functions of CANVAS the participants found helpful to improve their English. Question 27 asked the participants if they felt the tools used in their CE class enhanced their ability to learn with 103 (82.9\%) participants selected 7 or higher on a 10-point scale. Indicating that features provided by the LMS had a positive effect on their learning. Only $10(8 \%)$ responded negatively, with $7(5.6 \%)$ participants selecting 5, 2 (1.6\%) selecting 2 and $1(0.8 \%)$ participant selecting 1 . Out of these 10 participants, 6 were in the beginning level of English and 4 were in the intermediate level. Although not possible to prove from this data, there is an argument that the participants' lower level of English contributed to them responding negatively to this question. Further research comparing how students from different levels felt about how effective classes solely based on CANVAS were in improving learning would be needed.

Likewise, there were mainly positive responses to question 28 which asked the participants if CANVAS tools helped to improve their English ability. 99 (79\%) participants chose 7 or higher and only 5 respondents choosing 3 or less (See Figure 5). One participant elaborated by saying "The tools I used for this class were simple and easy to use which helped me to study well and improve my ability to learn". As for question 28, a participant responded negatively. "I don't think the tools improved my English ability as they were just a method to study 


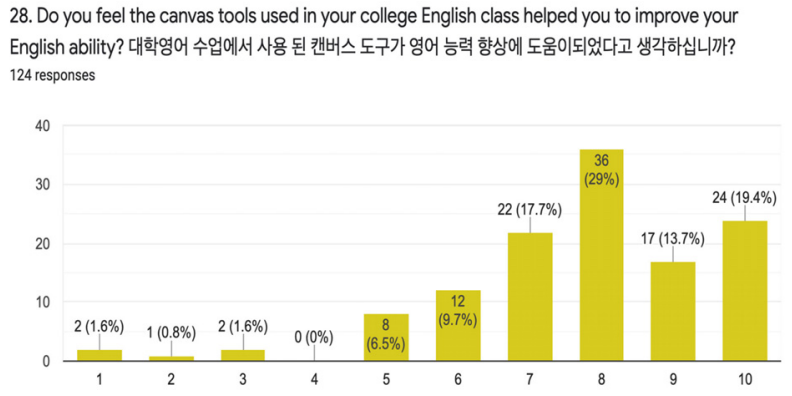

[Figure 5] Did CANVAS tools help improve your English ability?

an online class, but rather the class content and the teachers' explanations did."

Following on from this, survey question 30 examined whether the participants felt CANVAS helped to improve their English grade. 101 (81.4\%) participants selected 7 or higher on a 10-point scale with only $17(13.7 \%)$ selecting 5 or lower.

With the ultimate goal of CE classes being to develop students' English ability and grade, it was of interest as to why students responded negatively to question 28 and 30. As a result, the data from these participants was analyzed in more detail to try and understand their negative feelings. Interestingly, every participant who answered less than 5 for question 28 also answered with less than 5 for question 30 which appears to indicate students correlate English ability with achieving a high score for the class. There were no clear patterns in the data relating to age, English level, or grade for either of these questions.

Participants also respond affirmatively to survey question 31 which asked if feedback received via CANVAS tools help to improve their English ability. Over 80\% selected 7 or above with just over one third (33.2\%) selecting 10. This data clearly shows that feedback they received was a great source of help and assisted in improving their English. When asked about this in more detail via email, comments from a number of participants confirm this. "I liked getting regular comments from my teacher about my activity sheet and I could do better next class and on the exam."; "Comments on CANVAS comments box about my homework assignments really helped me to understand where my English is lacking." This study proves even during an era when more traditional face-toface feedback was not possible, comments and teacher input on student work appear to be just as important in improving English skills. These findings align with work done by Lee and Bailey (2016). Furthermore, CANVAS allows teachers to provide feedback through a variety of different methods including comments, personal messages, sample answers files and videos. The preferred method of feedback is unclear from this study and further research would be needed to establish this. However, unlike spoken feedback that might happen in physical classrooms, any feedback given on CANVAS can be replayed or re-read multiple times by learners which may help them to better understand the information they are being given and consequently improve as a result. One participant touched on this: "My teacher made an answers / feedback video I could watch after each class. I think it was good because I could take my time and review my answers carefully." This notion was also discussed by Tango Rojas (2020) and this study confirms that feedback via an LMS should also be considered a worthwhile way of improving student English ability.

\section{Conclusion and Implications}

This study was conducted under the unique circumstances of the ongoing global COVID-19 pandemic and there are several implications which can be taken from the findings. Firstly, and most importantly, despite some frustration, EFL learners in Korea were satisfied with CANVAS as an interface for online classes. In addition, although participants mentioned looking forward to returning to brick-and-mortar classes, the majority found CANVAS easy to use and were soon adapted with or without training. Furthermore, they were also satisfied with the LMS as it was a sufficient alternative to learn the material that would otherwise be learnt in class. Consequently, there is a strong argument for continued 
use of this LMS for EFL classes at Korean universities if classes need to be conducted online.

Secondly, whilst CANVAS offers wide range of features, participants felt only a few key ones were necessary to take classes and learn the course material. The most useful features were the lecture content, announcements, grades, assignments, and quizzes. Although administered online, these features seemed to replicate the way content would be delivered in a regular offline class. Contrary to this, participants seemed to be frustrated with some of the CANVAS features such as discussion and open board. These features did not reflect communicative activities which would happen in a classroom as the participants felt the delay in response to postings and the time and effort it took hindered the discussion. This information could help the developers of CANVAS with ideas for future updates.

A further implication relates to the features that the participants felt helped their progress and develop ability. Just like in a normal class, the participants are curious about their scores and progress. The grade section along with the feedback they received were welcomed tools. Participants could view individual assignments and quiz scores along with their total score and progress rate. In addition, the feedback participants received via comments box, email and announcements helped them understand if they were on track or needed to improve in specific areas. This shows that managing progress and feedback are a valuable source to improve their English ability during online classes. Given how valuable these functions appear to be to students, it is imperative they continue to be offered as part of the CANVAS package and possibly be further developed to offer greater levels of grade transparency and feedback.

A final implication from this study shows that communication between classmates was limited. Either participants were reluctant to email their peers or felt it was not necessary to do so. This implies learners are looking for more natural, interactive ways to communicate with their fellow learners and this appears to be a clear area for development in future versions of CANVAS.

\section{Limitations}

While the findings from this research have uncovered several interesting data points regarding how comfortable students were with using CANVAS, the features they liked and disliked, and if they helped to improve students' English ability, the authors are aware of several limitations to this study.

Firstly, it was conducted at one university that used CANVAS as the LMS platform from a survey pool of 124 participants with most of them taking their first CE class. Although attempts were made to collect the broadest range of data possible, a wider study with a greater number of participants from multiple universities would be needed and could be implemented for future research. Furthermore, there could be a difference in outcome if the pool included more students from different grades and who have taken more than one CE class. This study is also limited by the fact the perceptions of students from the three different proficiency groups were not compared. There is a possibility the data could show some variation if this was undertaken leading to an alternative insight into the three research questions.

Secondly, this study was solely based on classes that were taught asynchronously. While this is basically one of two ways to approach online classes, different results might have been seen if synchronous classes or a combination of both methods would have been examined.

Finally, a significant portion of research findings came from a survey and relatively short personal email communications. Arguably, if the research methodology was different, the results could possibly be more revealing. Therefore, a more detailed qualitative approach, including in-depth interviews and discussion groups would be needed to uncover further potential findings. 


\section{References}

Butakov, S., Solodky, O., \& Swar, B.(2013). "LMS implementation in startup institutions: Case study of three projects learning management systems and instructional design", In Best practices in online education (pp. 40-54), IGI Global.

Dang, T.(2020). "Factors Influencing Students' Perception of Usefulness of CANVAS as a Learning Management System", Unpublished doctoral dissertation, University of Gothenburg.

Dooley, L. M., Frankland, S., Boller, E., \& Tudor, E.(2018). "Implementing the flipped classroom in a veterinary preclinical science course: Student engagement, performance, and satisfaction", Journal of Veterinary Medical Education 45(2), 195-203.

Endozo, A. N., Oluyinka, S., \& Daenos, R.(2019). “Teachers' Experiences towards Usage of Learning Management System: CANVAS." Proceedings of the 2019 11th International Conference on Education Technology and Computers, Octo ber 2019, https://doi.org/10.1145/3369255.3369257

Green, R. A., Whitburn, L. Y., Zacharias, A., Byrne, G., \& Hughes, D. L.(2018). "The relationship between student engagement with online content and achievement in a blended learning anatomy course", Anatomical Sciences Education 11(5), 471-477.

Hajan, B., \& Padagas, R.(2021). "Blended Learning in a Research Writing Class: Perceptions and Experiences from ESL Secondary Learners", TESOLl International Journa, 16(4.4), 103-121.

Khoeri, A. F. A., Nuraini, W., Ramdani, R., \& Agum, S.(2021). "The implementation of CANVAS to enhance English teaching and learning", Proceedings International Conference on Education of Suryakancana, 2021, 315-320.

Kite, J., Schlub, T. E., Zhang, Y., Choi, S., Craske, S., \& Dickson, M.(2020). "Exploring lecturer and student perceptions and use of a learning management system in a postgraduate public health environment", E-Learning and Digital Media 17(3), 183-198. https://doi.org/10.1177/2042753020909217

Klobas, J. E., \& McGill, T. J.(2010). "The role of involvement in learning management system success", Journal of Computing in Higher Education, 22(2), 114-134.

Krause, K. L., \& Coates, H.(2008). "Students' engagement in first-year university", Assessment \& Evaluation in Higher Education 33(5), 493-505.

Lee, A., \& Bailey, D.(2016). 'Korean EFL Students' Perceptions of Instructor Video and Written Feedback in a Blended Learning Course", STEM Journal. 17(4), 133-158. doi: 10.16875/stem.2016.17.4.133

Morton, C. E., Saleh, S. N., Smith, S. F., Hemani, A., Ameen, A., Bennie, T. D., \& Toro-Troconis, M.(2016). "Blended learning: How can we optimize undergraduate student engagement?”, BMC Medical Education 16(1), 195.

Paulsen, M. F.(2003). "Experiences with learning management systems in 113 European institutions", Educational Technology \& Society 6(4), 134-148.

Pickering, J. D., \& Swinnerton, B. J.(2019). "Exploring the dimensions of medical student engagement with technologyenhanced learning resources and assessing the impact on assessment outcomes", Anatomical Sciences Education 12(2), 117-128.

Rabah, K.(2017). "The Future of Higher Educational Institutions (HEIs) in the Era of eLearning", Mara Research Journal of Information Science and Technology 1(1), 78-133, ISSN: 2518-8844.

Riddle, E., \& Gier, E.(2019). "Flipped classroom improves student engagement, student performance, and sense of community in a nutritional sciences course", Current Developments in Nutrition 3(1), 657-659.

Sawyer, A., Free, T., \& Martin, J. (2021). "Metagenomics: preventing future pandemics", Biotechniques 70(1), 1-4. https://doi.org/10.2144/btn-2020-0166

Soeung, C., Nakanitanon, P., \& Chaichompoo, C. (2020). "The Effects of Peer Feedback Activity Through CANVAS Learning Management System on Enhancing of Pannasastra University Students' English Writing Ability”, Journal of Graduate Research 11(2), 55-66. Retrieved from https://s o02.tci-thaijo.org/index.php/banditvijai/article/view/241952

Tango Rojas, J. S.(2020). "The Effect of Blended Learning on Language Proficiency of an EFL Class: An Empirical Study", Graduate Theses, Dissertations, and Problem Reports, 760 9, https://researchrepository.wvu.edu/etd/7609

Turnbull, D., Chugh, R., \& Luck, J.(2019). "Learning management systems: An overview", In Tatnall, A. (Ed.), Encyclopedia of Education and Information Technologies, Springer, Cham. https://doi.org/10.1007/978-3-319-60013-0_248-1

Weaver, D., Spratt, C., \& Nair, C. S.(2008). "Academic and student use of a learning management system: Implications for quality", Australasian Journal of Educational Technology, 24(1), 30-41.

Wilcox, D., Thall, J., \& Griffin, O.(2016). "One CANVAS, Two Audiences: How Faculty and Students use a Newly Adopted Learning Management System", In G. Chamblee, \& L. Langub (Eds.), Proceedings of Society for Information Technology \& Teacher Education International Conferenc $e$ (pp. 1163-1168), Savannah, GA, United States: Associati on for the Advancement of Computing in Education (AAC E). Retrieved July 28, 2021 from https://www.learntechlib. org/primary/p/171838/.

Young ,T. J.(2016). "Questionnaires and Surveys", In Zhu Hua, (Ed.), Research Methods in Intercultural Communication: A Practical Guide (pp. 165-180), Oxford: Wiley. 
Bahk, E. J.(2020, March). "College students unhappy with online lectures", The Korea Times, Retrieved from http://www.kor eatimes.co.kr/www/nation/2020/03/\%20113 285496.html

Edutechnica(2021). "LMS data-Spring 2021 updates" [Blog post], Retrieved from https://edutechnica.com/2021/06/21/lms-d ata-spring-2021-updates/

Hill, P.(2016). "MarketsandMarkets: Getting the LMS market wrong" [Blog post], e-Literate, Retrieved from https://mfel dstein.com/marketsandmarkets-getting-lms-market-wrong/

Hill, P.(2017). "State of higher ed LMS market for US and Canada: Spring 2017 edition" [Blog post], Retrieved from http://mfeldstein.com/state-higher-ed-lms-market-us-cana daspring-2017-edition

Kim, H. W.(2020). "대학가 동영상 강의 시대... 캔버스 LMS
관심", Retrieved from https://biz.sbs.co.kr/article/1000097 7368? division=NAVER

Lee, H. J.(2021). "Will Korea's herd immunity plan go smoothly?", The Korea Times, https://www.koreatimes.co.kr/www/nati on/2021/06/119 310023.html

Maske, P.(2020) "Importance of LMS software during COVID-19 pandemic", Education, Paradiso News, https://www.paradi sosolutions.com/blog/importance-lms-software-covid-19pandemic/

University Information Technology Services(UITS)(2013). "IU LMS pilots -A comparative functional review: Comparative functional review", Retrieved from https://assets.uits.iu.ed u/pdf/Comparative\%20Functional\%20Review.pdf 


\section{Appendix A}

CANVAS is the Learning Management System (LMS) that is integrated on Dankook University's website. This is called Elearning or Ecampus on our website, but the LMS platform is actually called CANVAS. CANVAS is used to administer your online English class and it is how you learn and submit your weekly work, assignments, quizzes, and exams. It also has other features to help you learn and communicate with your professor. This survey is trying to determine how effective you felt CANVAS was for College English classes and how it affected your learning experience. Please answer the following questions. If you have any questions about the survey, you can contact the research team at stu11@hotmail.com or andyrichards@hotmail.com

CANVAS는 단국 웹 사이트에 통합 된 학습 관리 시스템 (LMS)입니다. 웹 사이트에서는 Elearning 또는 Ecampus라 고하지만 LMS 플랫폼은 실제로 CANVAS라고합니다. CANVAS는 온라인 대학영어 수업을 관리하는 데 사용되며 주간 작업, 과제, 퀴즈 및 시험을 배우고 제출하는 방법입니다. 또한 교수님과 학습하고 의사 소통하는 데 도움이되는 다른 기능도 있습니다. 이 설문 조사는 CANVAS가 온라인 영어 수업에서 얼마나 효과적이라고 느꼈는지, 그리고 그것이 여러분의 학습 경험에 어떤 영향을 주 었는지 확인하기위한 것입니다. 다음 질문에 답해주십시오. 설문 조사에 대한 질문이있는 경우 stu11@hotmail.com 또는 andyrichards@hotmail.com으로 연구팀에 문의 할 수 있습니다.

1. Did you take at least one college English class online this semester?

이번 학기에 대학영어 수업을 한 번 이상 온라인으로 들었습니까?

O Yes / O No

2. Did your instructor mainly use canvas (e-learning) to conduct college English class? 강사가 대학영어 수업을 진행하기 위해 주로 캔버스 (e-learning)를 사용 했습니까?

$\mathrm{O}$ Yes / O No

3. Gender (성별)

O Male / O Female

4. Grade (학년)

O Freshman (1학년) / O Sophomore (2학년) / O Junior (3학년) / O Senior (4학년)

5. Age (나이)

$\mathrm{O} 19$ / O $20 / \mathrm{O} 21 / \mathrm{O} 22 / \mathrm{O} 23$ 이상

6. Major (전공)

$\mathrm{O}$ 문과대학 / $\mathrm{O}$ 법과대학 / $\mathrm{O}$ 사회과학대학 / $\mathrm{O}$ 상경대학 / $\mathrm{O}$ 공과대학 / $\mathrm{O}$ 자연과학대학 /

$\mathrm{O}$ 건축대학 / O SW융합대학 / O 사범대학 / O 예술디자인대학 / O 음악대학 / O 국제대학

7. English Level (현재 교양영어 분반 레벨?)

$\mathrm{O}$ Beginner (초급) / O Intermediate (중급) / O Advanced (고급) 
8. Overall, did you find Canvas easy to use during your college English course?

전 반적으로 대학영어 과정에서 Canvas를 사용하기 쉬웠습니까?

$\begin{array}{cccccccccccc}\text { Completely Disagree } & 1 & 2 & 3 & 4 & 5 & 6 & 7 & 8 & 9 & 10 & \text { Completely Agree } \\ \text { (완전히 동의하지 않음) } & \mathrm{O} & \mathrm{O} & \mathrm{O} & \mathrm{O} & \mathrm{O} & \mathrm{O} & \mathrm{O} & \mathrm{O} & \mathrm{O} & \mathrm{O} & \text { (완전히 동의함) }\end{array}$

9. Could you briefly explain why?

10. Prior to the start of the semester, did you receive any training on how to use Canvas?

학기 시작 전에 Canvas 사용법에 대한 교육을 받았습니까?

$\mathrm{O}$ Yes / O No

11. How long did it take to get used to using Canvas? 캔버스 사용에 익숙해지는 데 얼 마나 걸렸습니까?

O 1 day (1 일) / O 2-4 days (2 4 일) / O 1 week (1주 2주) / O Longer than 2 weeks (이주 이상)

12. Which of the following Canvas tools did you find most useful during the college English class that you took?

(You can choose more than one)

다음 중 대학영어 수업 에서 가장 유용하다고 생각한 캔버스 도구는 무엇입니까?

(여러 개를 선택할 수 있습니 다)
O Syllabus (수업 계획서)
$\mathrm{O}$ Lecture Contents (강의콘텐츠)
O Announcements (공지)
$\mathrm{O}$ Grades (성적)
O Lecture Resources (강의자료실)
$\mathrm{O}$ Gradebook (종합성적부)
O Open Board (열린게시판)
O Inbox (메시지함)
O Q \& A Board (문의게시판)
O Comments Box (댓글)
O Assignments (과제 및 평가)
O Dashboard (대시보드)
$\mathrm{O}$ Quizzes (시험 및 설문)
$\mathrm{O}$ Calendar (캘린더)
$\mathrm{O}$ Discussion (토론)
O None

13. Could you briefly explain why?

14. Which of the following Canvas tools did you find easy to use / user friendly?

(You can choose more than one)

다음 캔버스 도구 중 사용하기 쉽고 사용자 친화적인 도구는 무엇입니까?

(둘 이상 선택할 수 있음)

O Syllabus (수업 계획서)

O Lecture Contents (강의콘텐츠)

O Announcements (공지)

$\mathrm{O}$ Grades (성적)

O Lecture Resources (강의자료실)

$\mathrm{O}$ Gradebook (종합성적부)

O Open Board (열린게시판)

O Inbox (메시지함) 

O Q \& A Board (문의게시판)
O Comments Box (댓글)
$\mathrm{O}$ Assignments (과제 및 평가)
O Dashboard (대시보드)
$\mathrm{O}$ Quizzes (시험 및 설문)
O Calendar (캘린더)
$\mathrm{O}$ Discussion (토론)
O None

15. Could you briefly explain why?

16. Which of the following Canvas tools did you find difficult to use / unuser friendly?

(You can choose more than one)

다음 캔버스 도구 중 사용하기 어렵거나 사 용자에게 친숙하지 않은 도구는 무엇입니까?

(여러 개를 선택할 수 있습니다)
O Syllabus (수업 계획서)
O Lecture Contents (강의콘텐츠)
O Announcements (공지)
$\mathrm{O}$ Grades (성적)
O Lecture Resources (강의자료실)
O Gradebook (종합성적부)
O Open Board (열린게시판)
O Inbox (메시지함)
O Q \& A Board (문의게시판)
O Comments Box (댓글)
$\mathrm{O}$ Assignments (과제 및 평가)
O Dashboard (대시보드)
$\mathrm{O}$ Quizzes (시험 및 설문)
O Calendar (캘린더)
O Discussion (토론)
O None

17. Could you briefly explain why?

18. Canvas tools used in my college English class helped me to communicate with my classmates. 대학영어 수업에 사용 된 캔버스 도구는 급우들과 의사 소통하는 데 도 움이되었습니다

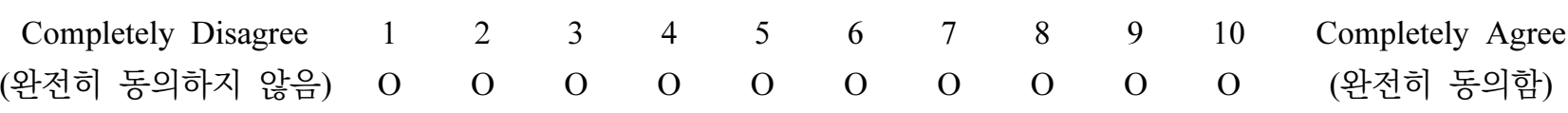

19. Why/why not?

20. Canvas tools used in my college English class helped me to communicate with my professor 대학 영어 수업에서 사용된 캔버스 도구들은 내가 나의 교수와 의사소통 하는 것을 도왔습니다

$\begin{array}{cccccccccccc}\text { Completely Disagree } & 1 & 2 & 3 & 4 & 5 & 6 & 7 & 8 & 9 & 10 & \text { Completely Agree } \\ \text { (완전히 동의하지 않음) } & \mathrm{O} & \mathrm{O} & \mathrm{O} & \mathrm{O} & \mathrm{O} & \mathrm{O} & \mathrm{O} & \mathrm{O} & \mathrm{O} & \mathrm{O} & \text { (완전히 동의함) }\end{array}$

21. Why/why not? 
22. Canvas tools used in my college English class helped me to track my progress in the class. 대학영어 수업에 사용 된 캔버스 도구는 수업 진행 상황을 추적하는 데 도움이 되었습니다

$\begin{array}{llllllllllll}\text { Completely Disagree } & 1 & 2 & 3 & 4 & 5 & 6 & 7 & 8 & 9 & 10 & \text { Completely Agree }\end{array}$

$\begin{array}{lllllllllllll}\text { (완전히 동의하지 않음) } & \mathrm{O} & \mathrm{O} & \mathrm{O} & \mathrm{O} & \mathrm{O} & \mathrm{O} & \mathrm{O} & \mathrm{O} & \mathrm{O} & \mathrm{O} & \text { (완전히 동의함) }\end{array}$

23. Canvas tools used in my college English class helped with getting feedback on my work?

대학영어 수업에 사용 된 캔버스 도구가 내 작업에 대한 피드백을받는 데 도 움이 되었습니까?

$\begin{array}{cccccccccccc}\text { Completely Disagree } & 1 & 2 & 3 & 4 & 5 & 6 & 7 & 8 & 9 & 10 & \text { Completely Agree } \\ \text { (완전히 동의하지 않음) } & \mathrm{O} & \mathrm{O} & \mathrm{O} & \mathrm{O} & \mathrm{O} & \mathrm{O} & \mathrm{O} & \mathrm{O} & \mathrm{O} & \mathrm{O} & \text { (완전히 동의함) }\end{array}$

24. Could you explain how?

25. Feedback received via Canvas tools was useful / effective?

캔버스 도구를 통해 받은 피드백이 유용했거나 효과적 이었습니까?

$\begin{array}{cccccccccccc}\text { Completely Disagree } & 1 & 2 & 3 & 4 & 5 & 6 & 7 & 8 & 9 & 10 & \text { Completely Agree } \\ \text { (완전히 동의하지 않음) } & \mathrm{O} & \mathrm{O} & \mathrm{O} & \mathrm{O} & \mathrm{O} & \mathrm{O} & \mathrm{O} & \mathrm{O} & \mathrm{O} & \mathrm{O} & \text { (완전히 동의함) }\end{array}$

26. Overall the canvas tools used in my college English class were useful / helpful? 대학영어 수업에 사용 된 캔버스 도구가 전반적으로 유용 했습니까?

$\begin{array}{cccccccccccc}\text { Completely Disagree } & 1 & 2 & 3 & 4 & 5 & 6 & 7 & 8 & 9 & 10 & \text { Completely Agree } \\ \text { (완전히 동의하지 않음) } & \mathrm{O} & \mathrm{O} & \mathrm{O} & \mathrm{O} & \mathrm{O} & \mathrm{O} & \mathrm{O} & \mathrm{O} & \mathrm{O} & \mathrm{O} & \text { (완전히 동의함) }\end{array}$

27. Do you feel the Canvas tools used in your college English class enhanced your learning? 대학영어 수업에서 사용되는 Canvas 도구가 학습을 향상 시켰다고 생각하 십니까?

$\begin{array}{cccccccccccc}\text { Completely Disagree } & 1 & 2 & 3 & 4 & 5 & 6 & 7 & 8 & 9 & 10 & \text { Completely Agree } \\ \text { (완전히 동의하지 않음) } & \mathrm{O} & \mathrm{O} & \mathrm{O} & \mathrm{O} & \mathrm{O} & \mathrm{O} & \mathrm{O} & \mathrm{O} & \mathrm{O} & \mathrm{O} & \text { (완전히 동의함) }\end{array}$

28. Do you feel the canvas tools used in your college English class helped you to improve your English ability? 대학영어 수업에서 사용 된 캔버스 도구가 영어 능력 향상에 도움이되었다고 생각하십니까?

$\begin{array}{cccccccccccc}\text { Completely Disagree } & 1 & 2 & 3 & 4 & 5 & 6 & 7 & 8 & 9 & 10 & \text { Completely Agree } \\ \text { (완전히 동의하지 않음) } & \mathrm{O} & \mathrm{O} & \mathrm{O} & \mathrm{O} & \mathrm{O} & \mathrm{O} & \mathrm{O} & \mathrm{O} & \mathrm{O} & \mathrm{O} & \text { (완전히 동의함) }\end{array}$

29. Could you explain how?

30. Do you feel the canvas tools used in your college English class helped you to improve your English grade? 대학영어 수업에서 사용되는 캔버스 도구가 영어 성적 향상에 도움이된다고 생각하십니까?

$\begin{array}{cccccccccccc}\text { Completely Disagree } & 1 & 2 & 3 & 4 & 5 & 6 & 7 & 8 & 9 & 10 & \text { Completely Agree } \\ \text { (완전히 동의하지 않음) } & \mathrm{O} & \mathrm{O} & \mathrm{O} & \mathrm{O} & \mathrm{O} & \mathrm{O} & \mathrm{O} & \mathrm{O} & \mathrm{O} & \mathrm{O} & \text { (완전히 동의함) }\end{array}$


31. Feedback received via Canvas tools help me to improve my English ability.

Canvas 도구 를 통해받은 피드백은 저의 영어 능력 향상에 도움이됩니다

$\begin{array}{cccccccccccc}\text { Completely Disagree } & 1 & 2 & 3 & 4 & 5 & 6 & 7 & 8 & 9 & 10 & \text { Completely Agree } \\ \text { (완전히 동의하지 않음) } & \mathrm{O} & \mathrm{O} & \mathrm{O} & \mathrm{O} & \mathrm{O} & \mathrm{O} & \mathrm{O} & \mathrm{O} & \mathrm{O} & \mathrm{O} & \text { (완전히 동의함) }\end{array}$

32. Would you be willing to discuss some of your responses in this survey with a member of the research team? 이 설문 조사에서 응답한 내용 중 일부를 연구팀 과 상의할 의향이 있으십니까?

$\mathrm{O}$ Yes

O No

33. If you would be happy to discuss some your answers in more detail with one of the members of the research team, please enter your contact details below.

귀하의 답변에 대해 연구팀 구성원 중 한 명과 더 자세히 논의하고자 하는 경우 아래에 연락처 세부 정보를 입력하십시오.

Name / 이름 / E-mail address / 이메일)

34. Do you consent to this data being used for research purposes? Any data submitted will be reviewed by this research team only and not shared with any $3^{\text {rd }}$ party. Any research conducted using this data will not be done for profit or personal financial gain.

이 데이터가 연구 목적으로 사용되는 것에 동의하십니까? 제출된 데이터는 본 연구팀에 의해서만 검토되고 제3자와 공유되지 않습니다. 이 데이터를 사용하여 수행되는 어떠한 연구도 영리 또는 개인적 금전적 이익을 위해 수행되지 않습니다

$\mathrm{O}$ Yes

O No 


\section{COVID-19 중 의 캔버스 기반 EFL 수업에 대한 학생들의 인식}

- 사례연구

앤드류 리차드스 ${ }^{1}$, 스튜어트 존스루

${ }^{1}$ 단국대학교 조교수

단국대학교 조교수

초록

이 연구는 세계적인 COVID-19 대유행 기간 동안 온라인 교육 매체로 CANVAS를 사용하는 것에 대한 한국 대학의 영어 학습자들의 느낌과 인식을 조사하기 위해 고안되었습니다. 데이터는 서울 지역의 한 대학에 등록된 129 명의 학생들로부터 수집되었습니다. 리커트 척도 및 개방형 질문의 객관식 조합으로 구성된 설문지가 주요 데이터 수집 방법으로 사용되었습니다. 또한, 동의가 이루어진 경우, 설문 조사 참가자들에게 이메일로 연락하여 자세한 답변을 논의했습니다. 데이터는 일반적인 정성 분석을 사용하여 분석되었고 기술 통계를 사용하여 논의되었습니다. 이 연구 결과는 유행병과 관련된 혼란과 시스템의 효율성과 관련된 좌절감에도 불구하고, 학생들은 그들의 주요 학습 인터페이스로 캔버스를 사용하는 것에 빠르게 적응할 수 있었고 일반적으로 만족했다는 것을 보여줍니다. 게다가, 그들은 학습 과정과 영어 능력 향상에 도움이 되는 특정한 수의 캔버스 기능에 의존했습니다. 이러한 연구 결과의 행정적, 교육적 의미와 한계도 논의됩니다.

주제어: 외국어로서의 영어, 코로나 19 , 캔버스, 교양영어교육, 학습관리시스템 